\title{
QUALITY MANAGEMENT SYSTEM TO IMPROVE THE QUALITY AND EFFICIENCY OF THE PRODUCTION OF BUTTERMILK WITH MUSHROOMS
}

\author{
POPA Oana ${ }^{1}$ and CONSTANTINESCU Adelina ${ }^{2}$ \\ 1’Lucian Blaga" University of Sibiu, oana.popa@ulbsibiu.ro \\ 2’Lucian Blaga" University of Sibiu, adelina.constantinescu@ulbsibiu.ro
}

\begin{abstract}
In order to obtain safe and high quality dairy products, fermented dairy processors implement and maintain procedures based on HACCP principles, which are based on a systemic approach to risks and corrective measures to eliminate any potential risk associated with food safety. The aim of this study was to use tools to analyze hazard, risk assessment and determine critical control points during the production process of buttermilk with mushrooms as an innovative product. The safety control system for fermented dairy products based on HACCP concepts, involves a systemic approach to risks and corrective measures to eliminate any potential risk associated with food safety.
\end{abstract}

KEY WORDS: innovative, HACCP, buttermilk, food safety

\section{INTRODUCTION}

The quick evolution of processing technology and the emergence of modern equipment, has led to the processing of dairy products obtained from different types of milk and with different vegetable ingredients. [1,2]

The origin of fermented dairy products is not known exactly, but according to Pederson (1979), fermented milk was produced 15,000 years ago when the human way of life went from the status of "food collector" to that of "producer". [3]

Fermented milk belongs to the category of acidic dairy products whose purpose is to serve as food after the fermentation operation with the help of lactic acid bacteria. [4]

Milk and dairy products are the most important and consumed products by a wide range of consumers, so it is necessary that all efforts are focused on the quality of buttermilk and the process of obtaining it. [5]

Taking into account consumer demand for dairy products with a beneficial effect on health, in recent decades, there have been new trends in the market of fermented dairy products that lead to various products with a high functional and nutritional value. [6]

The rapid processing of innovative fermented dairy products [7], the acceptance of these limes by consumers and the nutritional composition vary greatly. Ensuring sustainable quality management in the field of innovative dairy processing is an essential condition of the market economy and is a prior condition for an efficient and successful collaboration between processor and consumer. [8]

The use of various plants, spices, vegetables, fruits have led to fermented dairy products rich in bioactive compounds, with high antioxidant activity, as well as an increase in some components. $[9,10]$.

A consumer demand is related to the texture including firmness, consistency or viscosity of dairy products, which can be improved by adding stabilizers, dietary fiber or nutritional and functional ingredients. [11] It is also noted that the development of innovative dairy processing is done by both large processors and small producers. [12]
The HACCP plan belongs to safety, it is a document for the implementation of control actions through prevention and control measures signaled at the identified critical control points (CPC).

The critical control points identified during the implementation of the HACCP plan are the most important steps where it is possible to eliminate or reduce the risks that affect food safety. [13].

The aim of this paper is to develop a HACCP plan to ensure the safety of fermented milk production with the addition of mushrooms to see what factors in the production process of the innovative product may occur and which may influence its quality and also once identified how be kept under control.

In the HACCP study, SWOT analysis was used in order to identify the strategic market position of the whipped milk production unit.

SWOT (Strengths Weaknesses Opportunities Threats) analysis is one of the most widely used methods of analyzing a business. SWOT analyzes assesses the impact of strengths, weaknesses, opportunities and threats. [14]

The main purpose of the SWOT analysis is to identify and assign to each factor, positive or negative, one of the four categories.

SWOT analysis is a useful tool in developing and confirming the company's marketing technique and strategy.

Strong points: - what unique resources do we have?

- what are we better at?

- what technology do we use?

- what experience does our team have?

Weaknesses: - what are we weakest at?

- what should be improved?

- what are the disadvantages of the project?

Opportunities: - what new technology can we use?

- what new markets could open up?

- where can a competitive advantage be created? 
Threats: - is there competition on the market?

- what could the competition do to our detriment?

- what changes in customer preferences could be a threat?

In making quality products, the Deming cycle is used, considered an algorithm of actions that is repeated cyclically to manage the process and achieve its objectives. This approach is based on a continuous process of improving activities and is implemented due to the principle of continuous improvement. [15]

Deming considered that undertaking actions to promote quality management involves adopting a model, perceived as a program in the form of the Plan-Do-Check-Act (PDCA), which determines the sequential quality processes in the processor design:

P (Plan) - Plans: involves establishing the objectives and processes necessary to obtain results in accordance with the organization's policies and customer requirements;

D (Do) - Performs: involves the implementation of processes;

C (Check) - Verify: involves monitoring specific quality management processes and reporting results;

A (Act) - Acts: involves the enterprise itself to actions designed to support the continuous improvement of process performance.

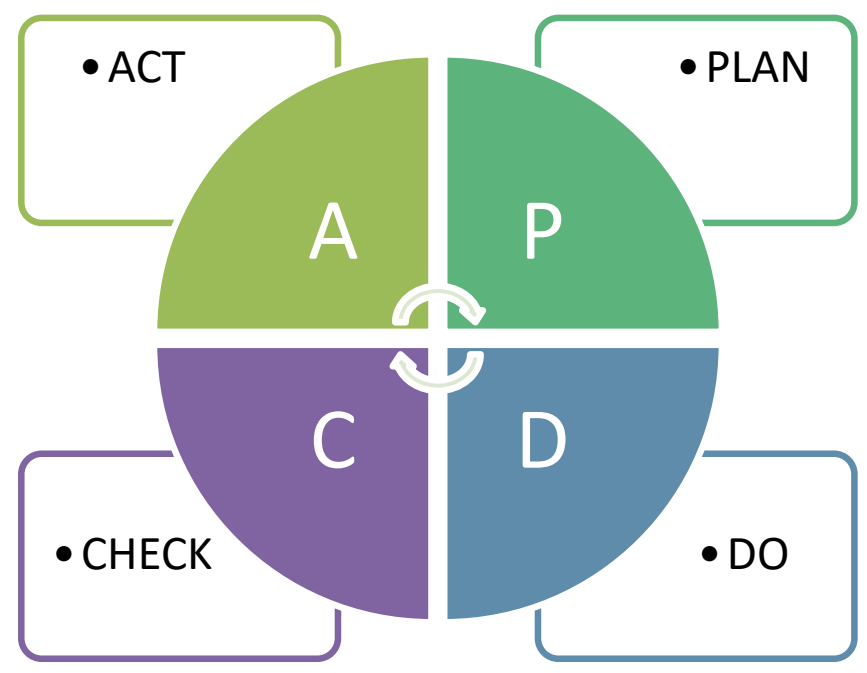

Figure 1. The Deming cycle.

\section{MATERIALS AND METHODS}

The object of the research was to follow the technological process of obtaining buttermilk with the addition of mushrooms based on the technological scheme below.

\section{Identification of potential hazards}

The HACCP plan must be applied for each stage of the technological scheme present in Fig. 2, from the stage of receiving the raw materials until the delivery of the finished product.

The analysis of the stages of the technological scheme shows the following physical, chemical and microbiological aspects presented in Tab.1 that must be observed in order to obtain a safe product from the HACCP point of view. 


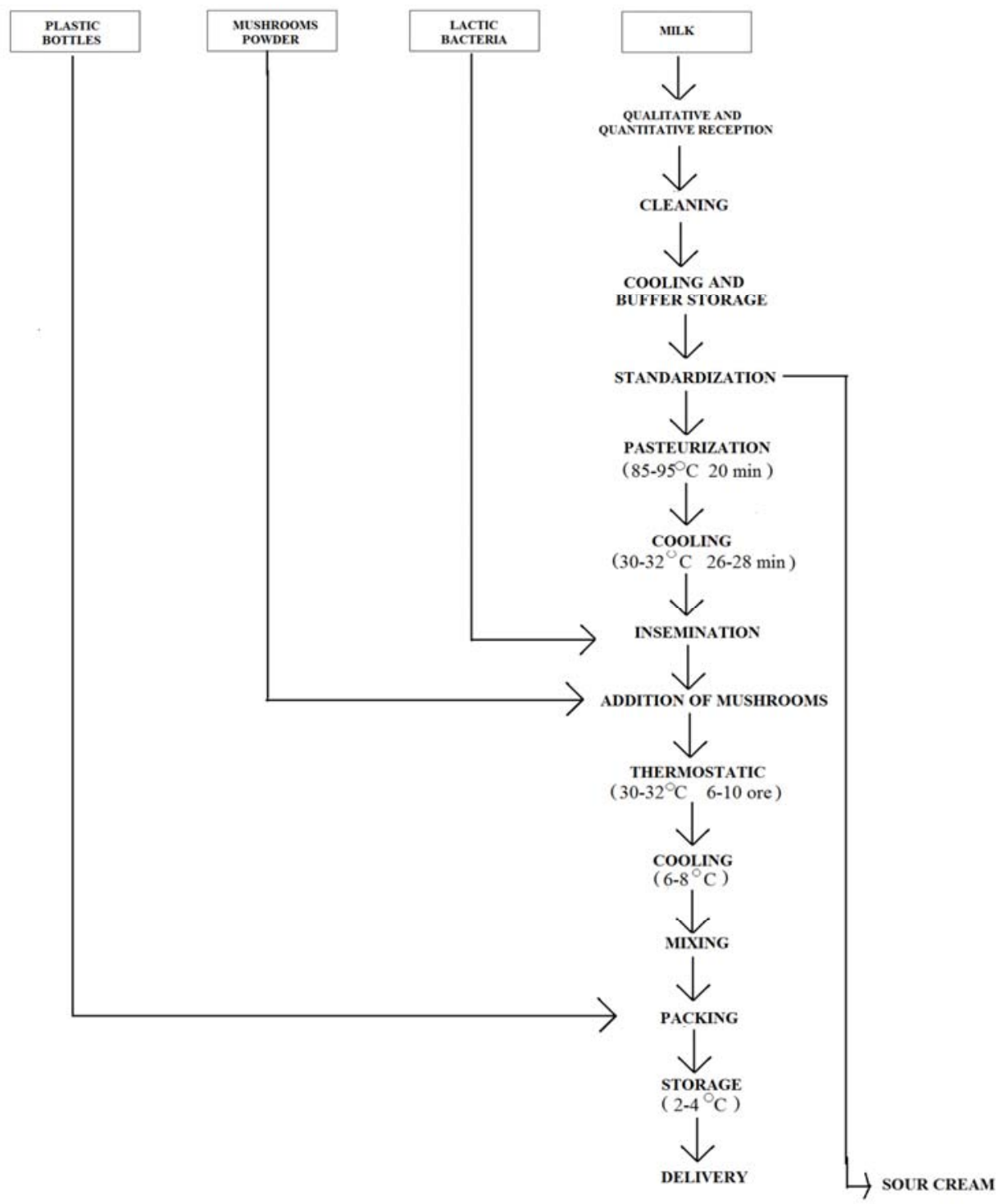

Figure 2. Technological scheme for obtaining buttermilk with mushrooms.

Table 1. Identification of potential hazards.

\begin{tabular}{|c|c|c|c|c|}
\hline $\begin{array}{l}\mathrm{Nr} \\
\mathrm{crt}\end{array}$ & Process stage & $\begin{array}{l}\text { Potential hazards } \\
\text { physical, chemical, } \\
\text { microbiological }\end{array}$ & Cause & Preventive measures \\
\hline 1 & $\begin{array}{l}\text { Qualitative and } \\
\text { quantitative } \\
\text { reception }\end{array}$ & $\begin{array}{l}\text { (F) Presence in milk } \\
\text { of: hairs, epithelial } \\
\text { cells, vegetable hairs } \\
\text { (fodder); } \\
\text { (C) Antiseptics and } \\
\text { antibiotics; } \\
\text { (M) Large number of } \\
\text { germs; large number of } \\
\text { butyric bacteria; }\end{array}$ & $\begin{array}{l}\text { - local treatment of } \\
\text { mastitis in cows; } \\
\text { - harvesting in improper } \\
\text { hygiene conditions, } \\
\text { storage at high } \\
\text { temperatures; } \\
\text { - silage; } \\
\text { - due to the long } \\
\text { transport time; } \\
\text { - due to } \\
\text { equipment; } \\
\text { - when taking samples }\end{array}$ & $\begin{array}{l}\text { - high temperature } \\
\text { pasteurization } \\
\text { - use of a good quality } \\
\text { silo (pH, 3.8), } \\
\text { especially corn; } \\
\text { - washing and cleaning, } \\
\text { - bacteriological control } \\
\text { of cleaning; } \\
\text { - good organization of } \\
\text { the collection activity }\end{array}$ \\
\hline 2 & Cleaning & $\begin{array}{l}\text { (F) Foreign bodies, } \\
\text { metals }\end{array}$ & - lack of hygiene & $\begin{array}{l}\text { - advanced filtration } \\
\text { and cleaning }\end{array}$ \\
\hline
\end{tabular}




\begin{tabular}{|c|c|c|c|c|}
\hline 3 & $\begin{array}{l}\text { Cooling and } \\
\text { buffer storage }\end{array}$ & $\begin{array}{l}\text { (F) Mistakes in } \\
\text { acidifying milk }\end{array}$ & - lack of hygiene & $\begin{array}{l}\text { - periodic verification } \\
\text { and observance of the } \\
\text { temperature regime }\end{array}$ \\
\hline 4 & Standardization & $\begin{array}{l}\text { (F) Mistakes in } \\
\text { acidifying milk }\end{array}$ & - lack of hygiene & $\begin{array}{l}\text { - checking the } \mathrm{pH} \\
\text { periodically and } \\
\text { observing its regime }\end{array}$ \\
\hline 5 & Pasteurization & $\begin{array}{l}\text { (M) Denaturation of } \\
\text { milk or incomplete } \\
\text { destruction of } \\
\text { microorganisms, } \\
\text { butyric bacteria }\end{array}$ & $\begin{array}{l}\text { - exceeding or reaching } \\
\text { the pasteurization } \\
\text { temperature or short } \\
\text { maintenance time } \\
\text { - equipment failures } \\
\text { - improper sanitation of } \\
\text { equipment } \\
\end{array}$ & $\begin{array}{l}\text { - temperature check; } \\
\text { - value of pasteurization } \\
\text { time (flow control); } \\
\text { - checking the } \\
\text { pasteurization result; } \\
\text { - technical service and } \\
\text { regular inspection }\end{array}$ \\
\hline 6 & Cooling & $\begin{array}{l}\text { (M) Destruction of the } \\
\text { coagulating enzyme; } \\
\text { - destruction of } \\
\text { pathogenic microflora } \\
\text { from contamination }\end{array}$ & $\begin{array}{l}\text { - exceeding the } \\
\text { temperature required for } \\
\text { the coagulation process }\end{array}$ & $\begin{array}{l}\text { - observance of the } \\
\text { temperature regime; } \\
\text { - tank temperature } \\
\text { measurement }\end{array}$ \\
\hline 7 & Insemination & $\begin{array}{l}\text { (M) Increased acidity } \\
\text { and cultures of infected } \\
\text { bacteria } \\
\text { (C) Detergents }\end{array}$ & $\begin{array}{l}\text { - adding a larger amount } \\
\text { of CaCl2 } \\
\text { - sowing a culture of } \\
\text { healthy lactic acid } \\
\text { bacteria; } \\
\text { - inadequate sanitation } \\
\text { of equipment }\end{array}$ & $\begin{array}{l}\text { - observance of the } \\
\text { amount of sowing } \\
\text { culture; } \\
\text { - personal training, } \\
\text { good hygiene and } \\
\text { production practices, } \\
\text { pH tests, equipment } \\
\text { maintenance }\end{array}$ \\
\hline 8 & $\begin{array}{l}\text { Addition } \\
\text { mushrooms }\end{array}$ & $\begin{array}{l}\text { (M) Pathogenic } \\
\text { bacteria } \\
\text { (C Detergents }\end{array}$ & $\begin{array}{l}\text { - processing mushrooms } \\
\text { under conditions that do } \\
\text { not meet hygiene } \\
\text { standards; } \\
\text { - inadequate sanitation } \\
\text { of equipment }\end{array}$ & $\begin{array}{l}\text { - personal training; } \\
\text { - good hygiene and } \\
\text { production practices }\end{array}$ \\
\hline 9 & Thermostatic & $\begin{array}{l}\text { (M) Development of } \\
\text { other microorganisms, } \\
\text { bacteria }\end{array}$ & $\begin{array}{l}\text { - temperature higher or } \\
\text { lower than necessary }\end{array}$ & $\begin{array}{l}\text { - maintaining } \mathrm{a} \\
\text { temperature of } 30-32^{\circ} \mathrm{C} \\
\text { or } 24-28^{\circ} \mathrm{C}\end{array}$ \\
\hline 10 & Cooling & (F) Increased acidity & $\begin{array}{l}\text { - non-compliance with } \\
\text { an adequate temperature }\end{array}$ & $\begin{array}{l}\text { - maintaining a } \\
\text { temperature of } 18-20^{\circ} \mathrm{C} \\
\text { or } 4-8^{\circ} \mathrm{C}\end{array}$ \\
\hline 11 & Mixing & & & \\
\hline 12 & Packing & $\begin{array}{l}\text { (M) Development of } \\
\text { putrefactive } \\
\text { microorganisms or } \\
\text { molds } \\
\text { (F) Foreign bodies, } \\
\text { metals }\end{array}$ & $\begin{array}{l}\text { - non-compliance with } \\
\text { the hygiene conditions } \\
\text { of packaging and } \\
\text { equipment }\end{array}$ & $\begin{array}{l}\text { - compliance with } \\
\text { hygiene conditions }\end{array}$ \\
\hline 13 & Storage & $\begin{array}{l}\text { (M) Development of } \\
\text { microorganisms on the } \\
\text { surface and inside the } \\
\text { milk }\end{array}$ & $\begin{array}{l}\text { - temperature exceeded } \\
\text { - incorrect relative } \\
\text { humidity }\end{array}$ & $\begin{array}{l}\text { - maintenance at a } \\
\text { temperature of } 4-6^{\circ} \mathrm{C}\end{array}$ \\
\hline
\end{tabular}

Once all possible risk factors have been identified in the technological scheme, the probability of occurrence of the risk or its severity must be analyzed. The probability of occurrence of risks is analyzed in four risk classes: zero, low, medium and high.

\section{Identification of Critical Control Points (CCP)}

The critical control points are determined by analyzing all stages of the production and technological process, the identified hazards are assessed on the basis of risk and the control measures are selected.

The number of critical control points for each process may vary depending on the type and complexity of the process, and when a large number of CCP occur it means that not all possibilities for prevention have been achieved. [5]

Determining the $\mathrm{CCP}$ at each stage of the process can reduce risks and improve product quality. This evaluation is made through the decision tree adapted to the HACCP plan of the system present in Tab. 2 which consists of a series of questions established and verified at each stage of the production flow.

By using the decision tree to follow each step in the technological process of production, a precise list of critical control points can be obtained. 
Table 2. CP/CCP identification.

\begin{tabular}{|c|c|c|c|c|c|c|}
\hline \multirow{3}{*}{ Stage } & \multirow{3}{*}{$\begin{array}{l}\text { Potential } \\
\text { hazards } \\
\text { physical, } \\
\text { chemical, } \\
\text { microbiologic } \\
\text { al }\end{array}$} & \multicolumn{4}{|c|}{ Nr. question (from the decision tree) } & \multirow{3}{*}{$\begin{array}{l}\text { CCP } \\
\text { Yes/No }\end{array}$} \\
\hline & & $\begin{array}{l}\text { Q1 Are there } \\
\text { preventive } \\
\text { measures to } \\
\text { prevent the } \\
\text { risk of } \\
\text { identified } \\
\text { hazards? }\end{array}$ & $\begin{array}{l}\text { Q2 Is that } \\
\text { step designed } \\
\text { to eliminate } \\
\text { the hazard or } \\
\text { reduce the } \\
\text { risk of the } \\
\text { hazard to an } \\
\text { acceptable } \\
\text { level? }\end{array}$ & $\begin{array}{l}\text { Q3 Is it } \\
\text { possible that } \\
\text { excessive } \\
\text { contamination } \\
\text { (an increase in } \\
\text { or above the } \\
\text { permissible } \\
\text { level) due to the } \\
\text { identified } \\
\text { hazards may } \\
\text { occur at this } \\
\text { stage? }\end{array}$ & $\begin{array}{l}\text { Q4 Is there a } \\
\text { further step } \\
\text { that can } \\
\text { eliminate or } \\
\text { reduce the } \\
\text { likelihood of } \\
\text { the identified } \\
\text { hazard to an } \\
\text { acceptable } \\
\text { level? }\end{array}$ & \\
\hline & & $\begin{array}{l}\text { NO - is not } \\
\text { CCP } \\
\text { YES - Q2 } \\
\end{array}$ & $\begin{array}{l}\mathbf{N O}-\mathrm{Q} 3 \\
\mathbf{Y E S}-\text { is } \\
\mathrm{CCP}\end{array}$ & $\begin{array}{l}\text { NO - is not } \\
\text { CCP } \\
\text { YES - Q4 }\end{array}$ & $\begin{array}{l}\text { NO - isCCP } \\
\text { YES - is not } \\
\text { CCP }\end{array}$ & \\
\hline $\begin{array}{l}\text { Qualitative and } \\
\text { quantitative } \\
\text { reception }\end{array}$ & $\mathrm{F}, \mathrm{C}, \mathrm{M}$ & Yes & No & No & - & No \\
\hline Clining & $\mathrm{F}$ & Yes & No & Yes & Yes & No \\
\hline $\begin{array}{l}\text { Cooling and buffer } \\
\text { storage }\end{array}$ & $\mathrm{F}$ & Yes & No & No & - & No \\
\hline Standardization & $\mathrm{F}$ & Yes & No & No & - & No \\
\hline Pasteurization & $\mathrm{M}$ & Yes & Yes & - & - & Yes - CCP 1 \\
\hline Cooling & M & Yes & No & Yes & Yes & No \\
\hline Insemination & $\mathrm{M}, \mathrm{C}$ & Yes & No & Yes & Yes & No \\
\hline $\begin{array}{l}\text { Addition of } \\
\text { mushrooms }\end{array}$ & $\mathrm{M}, \mathrm{C}$ & No & No & No & - & No \\
\hline Thermostatic & $\mathrm{M}$ & No & - & - & - & No \\
\hline Cooling & $\mathrm{F}$ & Yes & No & No & - & No \\
\hline \multicolumn{7}{|l|}{ Mixing } \\
\hline Packing & $\mathrm{M}, \mathrm{F}$ & No & - & - & - & No \\
\hline Storage & $\mathrm{M}$ & Yes & No & Yes & No & Yes - CCP 2 \\
\hline
\end{tabular}

\section{RESULTS AND DISCUSSIONS}

Once identified, corrective actions must be established for each determined CCP as set out in Tab.3 in accordance with system performance so that critical limits are observed and are maintained in optimal parameters for the system to operate in accordance with HACCP policies. and to obtain the desired product safely.

The HACCP system, as a preventive system, must be implemented initially for situations where the products do not meet the specified critical limits.

Thus, it is necessary to develop a system of corrective actions for each of the CCPs in order to reduce losses and make optimal decisions in the shortest possible time [6].

Regarding the development of the HACCP plan, the whipped milk product with the addition of mushrooms, the following main aspects can be highlighted:
- the analysis of the technological production scheme was performed;

- all possible risks have been identified, divided into biological, chemical and physical risks;

- 2 CCP were identified;

- monitoring and correction actions are proposed for the identified CCP cases. [7]

The Swot analysis, which presents an importance in the realization of quality products, regardless of the established actions, is presented in the table 4.

The Deming Cycle can be used as a guidance tool throughout the improvement process or for the development of innovative products when the needs for improvement have been identified.

The results obtained by applying the Deming cycle are presented in the table 5 .

Table 3. Corrective actions. 


\begin{tabular}{|c|c|c|c|c|c|}
\hline Operation & $\begin{array}{l}\mathbf{C C} \\
\mathbf{P}\end{array}$ & $\begin{array}{l}\text { Corrective } \\
\text { actions }\end{array}$ & Critical limits & $\begin{array}{l}\text { Ways of } \\
\text { surveillance }\end{array}$ & Corrective actions \\
\hline فี & $\begin{array}{l}\text { CCP } \\
1\end{array}$ & Scale control & $\begin{array}{l}\text { Maintenance } \\
\text { temperature } 85-95^{\circ} \mathrm{C} \text {, } \\
20-30 \text { minutes } \\
\text { according to the } \\
\text { Standards in force }\end{array}$ & $\begin{array}{l}\text { Measurement } \\
\text { of } \\
\text { pasteurization } \\
\text { at } 10 \text { min } \\
\text { intervals } \\
\text { Measurement } \\
\text { of duration } \\
\text { every } \\
\text { minutes }\end{array}$ & $\begin{array}{l}\text { If } \mathrm{t}^{\mathrm{o}} \text { is lower than the accepted value the } \\
\text { automatic valve must close the access } \\
\text { way to the tank and the pasteurization } \\
\text { must be repeated. } \\
\text { If the temperature is lower, the } \\
\text { pasteurization time is increased }\end{array}$ \\
\hline 萬 & $\begin{array}{l}\mathrm{CCP} \\
2\end{array}$ & $\begin{array}{l}\text { Temperature } \\
\text { control }\end{array}$ & $\begin{array}{l}\text { Temperature } 4-6^{\circ} \mathrm{C} \\
\text { according to the } \\
\text { Ssandards in force }\end{array}$ & $\begin{array}{l}\text { 12-hour } \\
\text { temperature } \\
\text { measurement }\end{array}$ & $\begin{array}{l}\text { Cooling systems are used with the help } \\
\text { of chillers (spray air, forced } \\
\text { circulation). }\end{array}$ \\
\hline
\end{tabular}

Table 4. Swot analysis.

\begin{tabular}{|l|l|}
\hline Strong points & Weaknesses \\
$\begin{array}{l}\text { - Implementation of food safety programs-HACCP } \\
\text { - The company is not dependent on a customer or a group } \\
\text { of customers } \\
\text { - Use of modern technologies and equipment } \\
\text { - Good organization of the advertising department } \\
\text { - Existence of qualified staff }\end{array}$ & $\begin{array}{l}\text { - Complete dissatisfaction with existing market demand } \\
\text { - The milk collection network is underdeveloped }\end{array}$ \\
\hline $\begin{array}{l}\text { Opportunities } \\
\text { - Entering new markets }\end{array}$ & \\
- High consumer interest \\
$\begin{array}{l}\text { - Finding sources of supply of cheaper raw materials } \\
\text { - Development of modern trade } \\
\text { - Leaving companies that will not implement EU rules in } \\
\text { time }\end{array}$ & $\begin{array}{l}\text { - Chreats } \\
\text { - Strong competition }\end{array}$ \\
\hline
\end{tabular}

Table 5. Deming Cycle.

\begin{tabular}{|l|}
\hline Strong points \\
\hline - complete dissatisfaction with existing market demand \\
\hline P expanding the production area \\
\hline D purchase of new equipment, hiring additional staff \\
\hline C sales monitoring \\
\hline A adoption of the strategy \\
\hline - the need for additional investment \\
\hline P accessing funds for concrete periods of time \\
\hline D finding sponsors to raise funds \\
\hline C checking their certainty \\
\hline A use of funds to improve the work carried out \\
\hline - the milk collection network is underdeveloped \\
\hline P orientation to other factories for the collection of raw materials \\
\hline D contacting new supply partners \\
\hline C checking the raw material \\
\hline A use the supplied product to improve production \\
\hline
\end{tabular}




\section{CONCLUSIONS}

This study showed that there is certainly a link between the implementation of a formalized system such as HACCP and the results of both in-process testing and analysis, as well as final testing and analysis in the development of an innovative fermented dairy product.

Applying the Swot analysis and the Deming cycle will have a significant impact on reducing the number of customer

\section{REFERENCES}

1. Tita, M.A. (2017) Obtaining a spreadable cheese sort with additives of bioactive compounds, Bulletin USAVM Animal Science and Biotechnologies, 74(2), 191-193.

2. Tita, M.A; Popovici, C. (2017) Research on obtaining freshcheese from goat's milk with tarragon, Analele Universitatii din Craiova, seria Biologie, Horticultura, Tehnologia Produselor Agricole, Ingineria Mediului, vol.XXII (LVIII) 1, 301-304.

3. Tamime A. Y.; Marshall V.M. (1997) Microbiology and technology of fermented milks, Microbiology and Biochemistry of Cheese and Fermented Milk.

4. ICMSF (1998) Milk and dairy products, Micro-organisms in Foods, 521

5. Burchi, F.; Fanzo, J.; Frison, E. (2011) The role offood and nutrition system approaches in tacklinghidden hunger. International Journal of Environmental Research and Public Health.

6. Tița, M.A.; Popovici, C.; Tamošaitienè, L.; Bradauskiene, V. (2020) Biological active compounds from native food sources for fermented dairy products, Ukrainian Food Journal, 9(1), 36-46.

7. Tiţa, M.; Shamtsyan, M. (2017) Research on the development and implementation of an innovative dairy product, 2017, Management of Sustainable Development, 9(2), 59-61.

8. Bătușaru, C.M. (2019) Sustainability of the small business environment in Romania in the context of increasing complaints and, more importantly, the risk to the customer that could be represented by the product.

Each processor understands that a specific control specific to each technology, will minimize the company's responsibility in terms of quality, social, economic, image and other factors that contribute to the success of any processor.

economic competitiveness, Management of Sustainable Development, 11(2).

9. Popovici, C.; Tita, M.A.; Brînza, R. (2018) Sensory evaluation and rheological behavoir of yogurts prepared from goat milk, 57th Annual scientific conference of University of Ruse and Union of Scientists, Bulgaria.

10. Tita, M.A.; Barca A. (2017) Comparative analysis of fermented milk products with and without added vegetable ingredients, Bulletin USAVM Animal Science and Biotechnologies, 74(2), 97-101.

11. Moga, V.M.; Tița, M.A. (2020) Marketing aspects of yoghurt enhanced with tapioca, Management of Sustainable Development, 12(2), 12-20.

12. Tița, M.A.; Popovici, C.; Tamošaitienè, L.; Bradauskiene, V. (2019) Research about sales possibilities of processed dairy products by small manufacturers, Management of Sustainable Development, 11(1), 29-31.

13. Worsfold, D.; Griffith, J. (2003) Widening HACCP implementation in the catering industry. Journal of Food Service Technology.

14. Nazarko, J.; Ejdys, J.; Halicka, K.; Magruk, A.; Nazarko, L.; Skorek, A. (2017) Application of Enhanced SWOT Analysis in the Future-oriented Public Management of Technology, Procedia Engineering 182, 482 - 490.

15. Kholif, A.M.; Abou El Hassan, D.S.; Khorshid, M.A.; Elsherpieny, E.A.; Olafadehan, O.A. (2018) Implementation of model for improvement (PDCA-cycle) in dairy laboratories, Journal of Food Safety, 38 (3). 